\title{
An Analysis of Cloud Computing Adoption Framework for Iraqi e-Government
}

\author{
Ban Salman Shukur, Mohd Khanapi Abd Ghani, M.A. Burhanuddin \\ Faculty of Information Communication Technology \\ University Teknikal Malaysia Melaka, \\ Hang Tuah Jaya, Durian Tunggal Melaka, MALAYSIA
}

\begin{abstract}
This paper presents an analysis of the factors which could have possible affect over the adoption of cloud computing via the Iraqi e-government. A conceptual framework model for cloud computing within Iraqi e-government is proposed, analyzed, evaluated and discussed.
\end{abstract}

Keywords-e-Government; cloud computing; framework; Iraq; Iraqi e-government

\section{INTRODUCTION}

The government of Iraq realizes the significance of the egovernment concept and the role of e-government to serve the Iraqi citizens and started the e-government project in 2004 after signing a memorandum between the Iraqi Ministry of Science and Technology (IMST) and the Italian government [1].

Unfortunately, like many growing countries, Iraqi's egovernment system still has a lot of obstacles, problems, challenges and difficulties which affect its development [2], [3].

Poor management of resources, infrastructure problems, lack in IT specialists who are required for developing and maintaining the Iraqi e-government system beside the problem of growing amount of data are some examples of obstacles which the Iraqi e-government project is actually facing [2]-[6].

Cloud computing, as a new technology has changed the way that organizations think about and use ICT from many perspectives. Within this subject, e-governments around the world are really looking into cloud computing as a solution for many problems like increasing efficiency, reducing cost, providing more reliable and efficient services, and reducing cycle time [7].

This paper presents a review of the factors which could have possible affect over the adoption of cloud computing via the Iraqi e-government in a new point of view to overcome its obstacles which already exist. A conceptual framework of cloud computing adoption for Iraqi e-government is proposed and evaluated by IT specialists in IMST who are actually in charge of this project in Iraq.

\section{E-GOVERNMENT}

\section{A. E-Governmnet Systems}

E-government systems have rapidly been implemented by developed as well as developing countries in different ways. Still, these implementation programs have varied widely in their scope, effectiveness, levels and benefits which they provide [8].

Shareef et al. defined e-government as a way for governments to use the most innovative information and communication technologies, especially web-based internet applications to provide their citizens and businesses with more suitable access to government information and services [9]. While the Organization for Economic Co-operation and Development (OECD) uses the term "e-government" to the internet usage in making government's services and/or information available for its citizens[10].

Most developing countries have experienced problems in implementing e-government systems, and most have remained at the early stages of their implementation [11]. Krishnan and Teo give a percentage for e-government systems' implementation in developing countries as a $35 \%$ for complete failure, $50 \%$ for partly failure and they consider that only $15 \%$ of such systems were considered to be successful [12].

Al-Khouri stated that the majority of e-government in Arab countries have failed and are stuck in the access phase of Forrester's maturity model, while the other evolved Arab countries in e-government are still in the early steps of the interaction phase [13]. Forrester's maturity model portrays three phases to evaluate e-government transformation era namely access, interaction, and integration.

\section{B. Benefits of E-Governmnets}

The adoption and use of the e-government strategy can provide significant benefits for government in delivering a more effective and efficient information and services to all egovernment sectors. It enables government agencies to align their efforts as needed to improve service and reduce operating costs [14].

Some of possible benefits of e-government implementation could be summarized in Table I.

Cost effectiveness is at the top of benefits which could be gained from a successful e-government system. Financial benefits are gained through cost reduction in reducing government transaction operations, reducing citizens' wasted time and efforts. Government's agencies will perform enhanced service quality for citizens and business and minimizing corruption and get the benefit of sharing information between them. This will built a better trust between government and its citizens. 
TABLE I. POSSIBLE BENEFITS OF E-GOVERNMENT IMPLEMENTATION

\begin{tabular}{|l|l|}
\hline Benefits & \multicolumn{1}{|c|}{ Authors } \\
\hline Financial & {$[15],[17],[18]$} \\
\hline Social & {$[15],[17,[18],[19]$} \\
\hline Government agencies & {$[15],[16],[19],[20]$} \\
\hline Economy & {$[17]$} \\
\hline Time Reduction & {$[18],[19],[20]$} \\
\hline $\begin{array}{l}\text { Achieve government's } \\
\text { objectives }\end{array}$ & {$[15],[16],[19]$} \\
\hline Sharing information & {$[16]$} \\
\hline $\begin{array}{l}\text { Built trust between government } \\
\& \text { citizens }\end{array}$ & {$[16]$} \\
\hline Improve efficiency & {$[16],[19],[20]$} \\
\hline
\end{tabular}

\section{Barriers of E-Government Implementation}

Implementing any e-system could also have its own barriers and challenges. The implementation, development and management of an e-government system could have possible barriers and challenges which could be classified to major barriers. Each of these barriers has its own sub-barriers and all of them must be taken into great attention. Technical barriers are considered the most challengeable ones when implementing a new e-government system, they affect over the development and implementation of an effective e-government system, especially in a developing country like Iraq. Within this category we can count the readiness of ICT infrastructure, privacy and security as the most challengeable barriers which most literature reviews agreed on.

Other main category is the organizational category counted the top management support and the existence of qualified people to develop, manage, supervise and maintain the egovernment system as sub-category's barriers do affect the implementation of e-government system, especially in developing and Arab countries like Iraq.

Table II shows a summary of possible barriers and challenges of E-Government implementation.

TABLE II. POSSIBLE BARRIERS OF E-GOVERNMENT IMPLEMENTATION

\begin{tabular}{|l|l|l|}
\hline Categories & E-government Barriers & \multicolumn{1}{|c|}{ Authors } \\
\hline \multirow{4}{*}{ Technical } & $\begin{array}{l}\text { The Creation of ICT } \\
\text { Infrastructure }\end{array}$ & {$[20],[21]$} \\
\cline { 2 - 3 } & Privacy & {$[22],[23]$} \\
\cline { 2 - 3 } & Security & $\begin{array}{l}{[14],[24],[22],[20],} \\
{[25],[26]}\end{array}$ \\
\hline \multirow{5}{*}{ Organization } & Top management support & {$[2],[27],[19],[29]$} \\
\cline { 2 - 3 } & $\begin{array}{l}\text { Lack of Qualified } \\
\text { Personnel and Training }\end{array}$ & {$[28],[29],[30]$} \\
\cline { 2 - 3 } & Lack of Collaboration & {$[28],[31],[32]$} \\
\cline { 2 - 3 } & $\begin{array}{l}\text { Resistance to change to } \\
\text { electronic ways }\end{array}$ & {$[28],[30]$} \\
\hline Social & Digital Divide & {$[19],[33]$} \\
\cline { 2 - 3 } & Culture & {$[19],[34]$} \\
\hline $\begin{array}{l}\text { Financial } \\
\text { Barriers }\end{array}$ & Cost & {$[35],[36]$} \\
\hline $\begin{array}{l}\text { Regulation and } \\
\text { Policy Issues }\end{array}$ & Laws and legal subjects & {$[37]$} \\
\hline
\end{tabular}

\section{Cloud COMPuting BenEFITS AND CHALLENGES FOR E-GOVERNMENT}

The most official and countable definition about cloud computing was introduced by the National Institute of Standard and Technology (NIST), which defined it as

"Cloud computing is a model for enabling convenient, ondemand network access to a shared pool of configurable computing resources (e.g., networks, servers, storage, applications, and services) that can be rapidly provisioned and released with minimal management effort or service-provider interaction" [38].

For an effective e-government system deployment, some necessary facilities and characteristics are vital to be available; such as easy maintenance, reliability, mobile access, and more available data storage. Beside that for most of developing countries, the cost of construction an e-government system is considered a major difficulty against establishment.

Cloud computing can offer great benefits for e-government systems and solve problems of high cost establishment, ease of use, more data storage, mobile access, scalability and automatic backup and recovery [39]-[43].

For that, researchers, IT specialists and other involved stakeholders evolved many researches and studies concerning the adoption of cloud computing via e-government systems.

Today, many governments in the world are already using cloud services or adopting some kind of cloud computing solutions within their e-governments' systems. Other governments are investigating and studying the possible affecting factors about adopting cloud computing within their e-governments' systems through strategic migration plans to assist their required daily functions and improve the service delivery level for their citizens [44].

Accordingly, the affecting factors about this adoption should be clearly discovered, discussed and understood before taking the adoption decision. A strategic mechanism should be held and a migration strategy into the new cloud computing adoption technology must be completely investigated in order to welcome a good decision making when steeping towards cloud computing adoption in an e-government system.

Possible benefits and positive influences in adopting cloud computing via an e-government system is shown in Table III.

TABLE III. BENEFITS IN ADOPTING CLOUD COMPUTING VIA EGOVERNMENT SYSTEM

\begin{tabular}{|l|l|}
\hline Benefits & Authors \\
\hline Easy to use \& easy Implementation & {$[46],[47],[48],[49],[42],[53]$} \\
\hline Scalability & {$[45],[46],[47],[48],[51],[42],[53]$} \\
\hline Cost Reduction \& Saving & {$[45],[46],[47],[48],[49],[42],[53]$} \\
\hline Backup and Recovery & {$[45],[47]$} \\
\hline Reduce local Data storage & {$[45],[51],[54],[50]$} \\
\hline Availability \& Accessibility & {$[45],[46],[47],[48],[42],[53]$} \\
\hline Green computing & {$[45],[46],[47],[49],[52]$} \\
\hline
\end{tabular}


TABLE IV. POSSIBLE CHALLENGES IN ADOPTING CLOUD COMPUTING VIA E-GOVERNMENT SYSTEM

\begin{tabular}{|l|l|}
\hline Challenges and Barriers & Authors \\
\hline Security & {$[45],[48],[42],[54]$} \\
\hline privacy & {$[45],[48],[42],[54]$} \\
\hline Internet dependency & {$[55],[64]$} \\
\hline Open standards and interoperability & {$[45],[42]$} \\
\hline Law and National and International Regulatory & {$[54]$} \\
\hline Business Reliable issues & {$[48],[42],[50],[54]$} \\
\hline Identity and access management & {$[45]$} \\
\hline
\end{tabular}

Although the attention of most countries in adopting cloud computing within e-government systems is significantly rising, still there are some countries which have a little knowledge and leadership's concerns regarding this adoption [55].

Most of governments' concerns come from the fact that they are uploading their confidential information to their egovernment systems and by adopting cloud computing within e-government system, the process of this information could be somewhere else outside the country beside the possibility of having a third party access to information.

This leads us to specify that security and privacy are the most important challenges which any government concern about when they are willing to adopt or use cloud within their e-government systems [56], [57].

Internet dependence and regularity issues are other concerning matters which should be encountered before choosing the appropriate cloud service provider(s), cloud service model(s) and cloud service deployment model(s).

Possible challenges in adopting cloud computing via egovernment system in Table IV.

\section{AdOPTION MODELS FOR CLOUd COMPUTING IN E-GOVERNMENT SYSTEMS}

To predict the adoption of new technology, like cloud computing, many well-known theories in information system (IS) field could be suggested and/or applied. Choosing suitable technologies and methods are compulsory for a good adoption practice to gain its valuable results.

Iraqi e-governments, as mentioned before, has some limitations, obstacles, challenges and some problems regarding its development and implementation process, which obviously have affected negatively on its completeness [3], [5] and [2]. For that, adopting cloud computing in the Iraqi e-government system requires a comprehensive analysis regarding the factors that could influence such adoption.

Pointing out such factors, will eventually leads to propose a realistic valuable framework that could be used to assists Iraqi government to step over problems and difficulties which the egovernment system in Iraq is suffering from. Within this perspective, there are two adoption models are discussed in this paper and considered to be used for the proposition of Iraqi cloud computing e-government adoption framework.
TABLE V. SUGGESTED ADOPTION MODELS FOR CLOUd COMPUTING IN E-GOVERNMENT SYSTEM

\begin{tabular}{|l|l|}
\hline Adoption Model of Cloud Computing in E-Government & Author \\
\hline TOE framework +People & {$[44]$} \\
\hline TAM+ (TRA) & {$[60]$} \\
\hline TOE framework & {$[61]$} \\
\hline TOE model + conceptual model of Cloud Computing adoption & {$[62]$} \\
\hline TOE framework & {$[63]$} \\
\hline Technological \& Organizational factors & {$[64]$} \\
\hline TAM & {$[65]$} \\
\hline
\end{tabular}

First, we discuss the Technology, Organization, and Environment (TOE) Framework, which is a theoretical framework that was developed by Tornatzky and Fleischer in 1990 and still widely used by IS researchers till now[58]. Within this framework, the components of an organization which is studying the adoption of new technology are classified into three major classifications; namely: Technological, Organizational and Environmental elements and the second model to be discussed here is the Technology Acceptance Model (TAM), which is mainly used to examine the user's interaction with the new innovation from two major points. The perceived usefulness (PU) which points to the degree of user's trust towards the new system and perceived ease of use (PEOU) which is the degree to which the user believes that using a particular system would be free of effort [59]. Table V shows a summary of suggested models in adopting cloud computing within e-government.

\section{FACTORS AFFECTING THE AdOPTION OF CLOUD COMPUTING VIA E-GOVERNMENT}

Scientific analysis with reliable bases should be implemented in order to drive a conceptual framework for the adoption of new technology. This matter is a big matter of importance, especially when the adoption decision could affect and affected by a system which is employed and operated by a government and used by all citizens. In addition, the local, region, religion, culture and legal characteristics and issues beside the uniqueness of each country should be considered and investigated.

Because of all the mentioned points, studying factors which may have affects over the adoption of a new technology from different perspectives, as researchers went through should be considered and taken care for.

Factors have their own positive or negative impact over the adoption of any new technology. The adoption of cloud computing via e-government is not an exception of this.

Possible affecting factors which could affect the adoption of cloud computing via e-government, from literature is summarized in Table VI. 
TABLE VI. FACTORS AFFECTING THE AdOPTION OF CLOUd COMPUTING VIA E-GOVERNMENT

\begin{tabular}{|c|c|c|}
\hline \multicolumn{2}{|l|}{ Affecting Factors } & Authors \\
\hline \multirow{7}{*}{ Technological context } & Cost saving $(+)$ & $\begin{array}{l}\text { [66], [67], [70], [71], [73], [74], [75], [76], [46], [45], [77], [78], [69], [79], [47], } \\
{[49],[80],[81],[68],[82],[64],[72],[83],[87]}\end{array}$ \\
\hline & Scalability (+) & $\begin{array}{l}{[66],[70],[71],[73],[75],[76],[46],[42],[74],[62],[79],[47],[80],[81],[61],} \\
{[63],[82],[64],[72],[87]}\end{array}$ \\
\hline & flexibility (+) & $\begin{array}{l}\text { [67], [49], [50], [73], [74], [75], [62], [79], [80], [81], [44], [61], [63], [82], [64], } \\
{[72],[83],[87]}\end{array}$ \\
\hline & Compatibility(+) & [75], [78], [79], [81], [81], [61], [64], [72] \\
\hline & Complexity(-) & [75], [78], [79], [80], [81], [61], [64], [72], [86] \\
\hline & Security \& privacy(-) & $\begin{array}{l}\text { [66], [67], [70], [71], [73], [74], [75], [76], [42], [77], [78], [62], [44], [82], [63], } \\
\text { [64], [86], [87] }\end{array}$ \\
\hline & Resource Utilization (+) & [66], [67], [70], [73], [45], [77], [44], [70], [82] \\
\hline \multirow{6}{*}{ Environmental Context } & Reliable(+) & [67], [73], [74], [69], [80], [81], [61], [83], [86] \\
\hline & Available (+) & [67], [73], [62], [79], [80], [81], [68], [83], [86] \\
\hline & Ownership (-) & [67], [73], [74], [79], [81], [63] \\
\hline & Mobile Access $(+)$ & {$[66],[67],[71],[73],[76],[45],[62],[79],[46],[82]$} \\
\hline & Migration(-) & [70], [71], [73] \\
\hline & Internet Connection & [70], [82] \\
\hline \multirow{3}{*}{ Organizational Context } & Top Management (+) & [75], [78], [79], [80], [81], [44], [61], [70], [64], [72] \\
\hline & IT infrastructure $(+)$ & [75], [42], [80], [81], [61], [63], [64], [72] \\
\hline & IT Human Resources $(+)$ & [75], [70], [81], [44], [61], [63], [82] \\
\hline \multicolumn{2}{|l|}{ Easy of Use (+) } & [67], [70], [73], [74], [46], [42], [47], [49], [82], [83] \\
\hline \multicolumn{2}{|l|}{ Regulation Issues } & {$[62],[70],[83]$} \\
\hline
\end{tabular}

\section{FACTORS AFFECTING CLOUD COMPUTING ADOPTION VIA IRAQI E-GOVERNMENT}

According to Table VI, there are 19 affecting factors which most researchers agreed on and they are divided into 5 major categories: namely, technological context, environmental context, organizational context, ease of use and regulation issues.

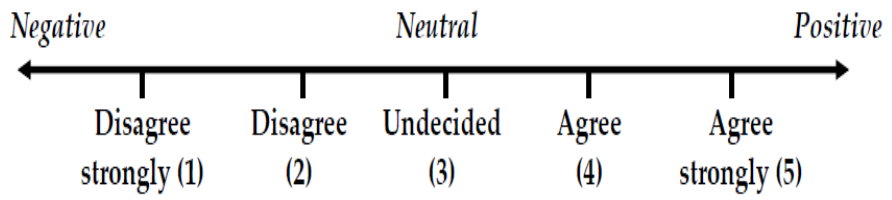

Fig. 1. Straightforward Notion for Likert [84]

However, these factors should be tested and evaluated by Iraqi IT specialists who are responsible of the e-government system within IMST to see if they are appropriate for Iraq or not. For that a questioner was conducted to evaluate these factors by above mentioned employees besides semi structured interviews to reach common understandings and solutions.

The sample included 25 participants, 15 participants were male and 10 of them female who have different job titles; namely: programmers, IT engineers, managers and experts, all of them working within the Iraqi e-government project in IMST / Information Technology section. They work as technicians, technical administrations, information engineers, programmers, managers and experts and varied in age between 20-60 years old.

Likert scale, which is one of the most important and frequently used tools by researchers in sciences was used to test whether the factors that affect the adoption of cloud computing within the Iraqi e-government have positive or negative impact over the adoption [85].

Likert suggested that a successful attitude measurement is to carry out the fundamentals measurements to review the respondents' options which best reflect their position on the 
measurement. Fig. 1 shows the Likart's measurements' notation [84].

For this paper's requirements, the respondents were asked to disclose the factors that could influence the adoption of cloud computing within e-government in Iraq. A 5-point Likert scale was used for questioner, where 1 point is accorded to strongly disagree, 2 points for disagree, 3 points for neutral (neither agree nor disagree), 4 points for agree and 5 points is a scale of strongly agree.

Table VII shows the main and sub categories with a suitable question statement representing the possible affecting factors which could have impact over the adoption of cloud computing via Iraqi e-government. This was the sample which was delivered for IMST employers who were the participants in this survey accompanied by Likert 5-point scale to select the suitable selection by them.

The results from this part of questioner were analyzed according to Likert's scale and the mean as well as the standard deviation (S.D) were calculated to validate suggested factors. These results which are illustrated in Table VIII shows clearly that most of suggested factors (all except the migration factor) have an excepted mean value $(>3.0)$ which means they are acceptable by the IT experts and employees who are actually working in the Iraqi e-government project at IMST.

S.D also pointed out a non-acceptable value $(<0.7)$ for migration factor.

TABLE VII. SAMPLE OF QUESTIONER FORM

\begin{tabular}{|c|c|}
\hline \multicolumn{2}{|c|}{ Technological Context } \\
\hline \multicolumn{2}{|c|}{ Statement } \\
\hline 1 & Is adopting cloud computing in Iraqi E-government system has a cost saving advantage impact factor over the system? \\
\hline 2 & Is adopting cloud computing in Iraqi E-government system has a flexibility advantage impact factor over the system? \\
\hline 3 & Is adopting cloud computing in Iraqi E-government system has a scalability advantages impact factor over the system? \\
\hline 4 & Is adopting cloud computing in Iraqi E-government system has a compatibility advantages impact factor over the system? \\
\hline 5 & Is adopting cloud computing in Iraqi E-government system has a complexity disadvantage impact factor over the system? \\
\hline 6 & Is adopting cloud computing in Iraqi E-government system has a security disadvantage impact factor over the system? \\
\hline 7 & Is adopting cloud computing in Iraqi E-government system has a privacy disadvantage impact factor over the system? \\
\hline 8 & Is adopting cloud computing in Iraqi E-government system has a resource utilization advantage impact factor over the system? \\
\hline \multicolumn{2}{|c|}{ Organizational Context } \\
\hline \multicolumn{2}{|c|}{ Statement } \\
\hline 9 & Is the top Management Support has a positive impact over the adoption of cloud computing within Iraqi E-government? \\
\hline 10 & Is adopting cloud computing in Iraqi E-government system has a positive impact over the IT infrastructure? \\
\hline 11 & Is adopting cloud computing in Iraqi E-government system has a positive impact over the IT Human Resources? \\
\hline \multicolumn{2}{|c|}{ Environmental Context } \\
\hline \multicolumn{2}{|c|}{ Statement } \\
\hline 12 & Is adopting cloud computing in Iraqi E-government system has a Reliability advantage impact over the system? \\
\hline 13 & Is adopting cloud computing in Iraqi E-government system has the availability advantage impact over the system? \\
\hline 14 & Is adopting cloud computing in Iraqi E-government system has an Ownership disadvantage impact over the system? \\
\hline 15 & Is adopting cloud computing in Iraqi E-government system has a Mobile Access advantage impact over the system?. \\
\hline 16 & Is adopting cloud computing in Iraqi E-government system has a Migration disadvantage impact over the system? \\
\hline 17 & Is adopting cloud computing in Iraqi E-government system can have the Internet Connection advantage impact over the system? \\
\hline \multicolumn{2}{|c|}{ Ease of Use } \\
\hline \multicolumn{2}{|c|}{ Statement } \\
\hline 18 & Is adopting cloud computing in Iraqi E-government system has an Easy of Use advantage impact over the system? \\
\hline \multicolumn{2}{|c|}{ Legal Issues } \\
\hline \multicolumn{2}{|c|}{ Statement } \\
\hline 19 & Is adopting cloud computing in Iraqi E-government system has a Legal Issue disadvantage impact over the system? \\
\hline
\end{tabular}


TABLE VIII. QUESTIONER RESULTS

\begin{tabular}{|c|c|c|c|}
\hline \multicolumn{4}{|c|}{ Technological Context } \\
\hline \multicolumn{2}{|c|}{ Statement } & \multirow{2}{*}{$\begin{array}{l}\frac{\text { Mean }}{4.6} \\
\end{array}$} & \multirow{2}{*}{$\begin{array}{l}\text { S.D } \\
0.63245553\end{array}$} \\
\hline 1 & $\begin{array}{l}\text { Is adopting cloud computing in Iraqi E-government system has a cost saving advantage } \\
\text { impact factor over the system? }\end{array}$ & & \\
\hline 2 & $\begin{array}{l}\text { Is adopting cloud computing in Iraqi E-government system has a flexibility advantage } \\
\text { impact factor over the system? }\end{array}$ & 3.96 & 0.91564185 \\
\hline 3 & $\begin{array}{l}\text { Is adopting cloud computing in Iraqi E-government system has a scalability advantages } \\
\text { impact factor over the system? }\end{array}$ & 4.52 & 0.75471849 \\
\hline 4 & $\begin{array}{l}\text { Is adopting cloud computing in Iraqi E-government system has a compatibility advantages } \\
\text { impact factor over the system? }\end{array}$ & 4.04 & 1.28 \\
\hline 5 & $\begin{array}{l}\text { Is adopting cloud computing in Iraqi E-government system has a complexity disadvantage } \\
\text { impact factor over the system? }\end{array}$ & 4.32 & 0.96829747 \\
\hline 6 & $\begin{array}{l}\text { Is adopting cloud computing in Iraqi E-government system has a security disadvantage } \\
\text { impact factor over the system? }\end{array}$ & 3.64 & 1.05375519 \\
\hline 7 & $\begin{array}{l}\text { Is adopting cloud computing in Iraqi E-government system has a privacy disadvantage } \\
\text { impact factor over the system? }\end{array}$ & 4.4 & 1.0198039 \\
\hline 8 & $\begin{array}{l}\text { Is adopting cloud computing in Iraqi E-government system has a resource utilization } \\
\text { advantage impact factor over the system? }\end{array}$ & 4.6 & 0.48989795 \\
\hline \multicolumn{4}{|c|}{ Organizational Context } \\
\hline \multicolumn{2}{|c|}{ Statement } & Mean & S.D \\
\hline 9 & $\begin{array}{l}\text { Is the top Management Support has a positive impact over the adoption of cloud computing } \\
\text { within Iraqi E-government? }\end{array}$ & 3.64 & 1.29243955 \\
\hline 10 & $\begin{array}{l}\text { Is adopting cloud computing in Iraqi E-government system has a positive impact over the } \\
\text { IT infrastructure? }\end{array}$ & 4.92 & 0.2712932 \\
\hline 11 & $\begin{array}{l}\text { Is adopting cloud computing in Iraqi E-government system has a positive impact over the } \\
\text { IT Human Resources? }\end{array}$ & 4.44 & 0.89799777 \\
\hline \multicolumn{4}{|c|}{ Environmental Context } \\
\hline \multicolumn{2}{|c|}{ Statement } & Mean & S.D \\
\hline 12 & $\begin{array}{l}\text { Is adopting cloud computing in Iraqi E-government system has a Reliability advantage } \\
\text { impact over the system? }\end{array}$ & 3.52 & 1.38910043 \\
\hline 13 & $\begin{array}{l}\text { Is adopting cloud computing in Iraqi E-government system has the availability advantage } \\
\text { impact over the system? }\end{array}$ & 4.2 & 1.16619038 \\
\hline 14 & $\begin{array}{l}\text { Is adopting cloud computing in Iraqi E-government system has an Ownership disadvantage } \\
\text { impact over the system? }\end{array}$ & 4.08 & 1.16344317 \\
\hline 15 & $\begin{array}{l}\text { Is adopting cloud computing in Iraqi E-government system has a Mobile Access advantage } \\
\text { impact over the system? }\end{array}$ & 4.4 & 0.8 \\
\hline \multicolumn{2}{|c|}{ Statement } & Mean & S.D \\
\hline 16 & $\begin{array}{l}\text { Is adopting cloud computing in Iraqi E-government system has a Migration disadvantage } \\
\text { impact over the system? }\end{array}$ & 2.92 & \\
\hline 17 & $\begin{array}{l}\text { Is adopting cloud computing in Iraqi E-government system can have the Internet } \\
\text { Connection advantage impact over the system? }\end{array}$ & 3.56 & 0.89799777 \\
\hline \multicolumn{4}{|c|}{ Ease of Use } \\
\hline \multicolumn{2}{|c|}{ Statement } & Mean & S.D \\
\hline 18 & $\begin{array}{l}\text { Is adopting cloud computing in Iraqi E-government system has an Easy of Use advantage } \\
\text { impact over the system? }\end{array}$ & 3.92 & 0.97652445 \\
\hline \multicolumn{4}{|c|}{ Legal Issues } \\
\hline \multicolumn{2}{|c|}{ Statement } & Mean & S.D \\
\hline 19 & $\begin{array}{l}\text { Is adopting cloud computing in Iraqi E-government system has a Legal Issue disadvantage } \\
\text { impact over the system? }\end{array}$ & 3.64 & 0.97488461 \\
\hline
\end{tabular}




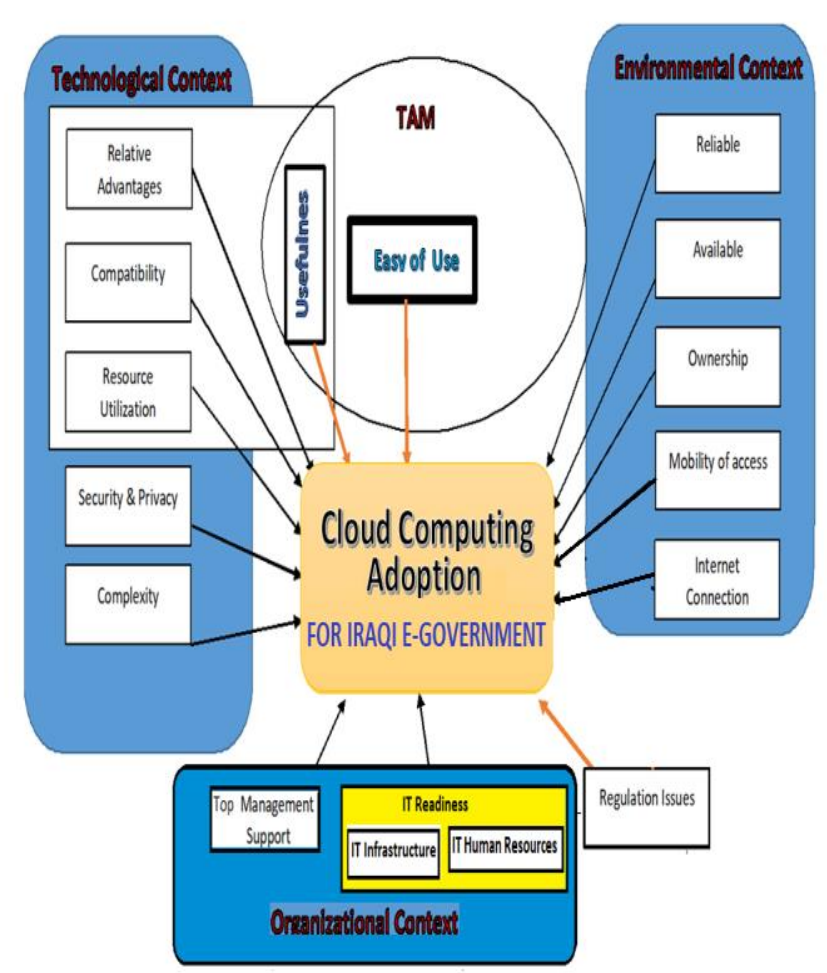

Fig. 2. Conceptual model for factors affecting cloud computing adoption for Iraqi e-government.

According to that, the migration factor was excluded from the conceptual framework model relating to the adoption of cloud computing in Iraqi e-government. Fig. 2 shows the resultant conceptual model for the factors affecting cloud computing adoption for Iraqi E-government.

\section{CONCLUSION}

There are many factors which need to be considered before adopting cloud computing in a new environment.

For a developing country like Iraq, which has its own circumstances and issues, developing a conceptual framework about the adoption of cloud computing should rely own solid scientific bases and goes through a lot of investigation and validation by specialized IT expertise and employees.

The conceptual model for factors affecting cloud computing adoption in Iraqi e-government was derived upon deep and wide verity of related literature review and has its own bases and theories of adoption which should be accounted to assure the right adoption context for a new innovation technology. From analyzing factors we saw that a TOE framework and TAM model with addition and modifications which researchers did concerning the uniqueness characteristics about Iraqi e-government was suitable as a theoretical framework and a model to be tested.

The outcomes was very corrigible and most factors extracted through literature review (all except one) were conferred to be affected factors if a cloud computing is to be chosen via Iraqi e-government system.

\section{REFERENCES}

[1] A.H. Abdul-Alrahman, "Human Resources Investment as an Introduction to improve the efficiency \& activity of workers in E Government" Journal: Journal of the planner and development, Issue: 24, 2011.

[2] A. Al-Dabbagh, "Former Spokesman: Iraqi Decision Makers Are Unqualified and Incompetent", 2014.

[3] A.A. Hassan, "Status of E-Government in Iraq and What the Challenges of Development and Implementation", International Journal of Science and Research (IJSR), Volume 5 Issue 5, 2015.

[4] H. Sabah, "Designing and Implementation Iraqi E-Government Front Office Online System”, Journal of Knowledge Management, Economics and Information Technology, Vol. IV, Issue 2, 2014.

[5] H.H. Mahmoud, "E-Government in Iraq", Journal of Engineering and Development, Vol. 14, No. 4, 2010.

[6] T. E. Ibrahim, "A Road Map to a Successful Application of EGovernment in Iraq". Çankaya University, 2014.

[7] A. Bisong, S. Syed \& M. Rahman, "An Overview of the Security Concerns in Enterprise Cloud computing", CoRR, 3(April 2012), 30-45

[8] M. Alsaif, “Factors affecting citizens' adoption of e-government moderated by socio-cultural values in Saudi Arabia", University of Birmingham, 2014.

[9] M.A. Shareef, V. Kumar, U. Kumar, \& Y.K. Dwivedi," E-Government Adoption Model (GAM): Differing service maturity levels" Government Information Quarterly, 28(1), 2011, 17- 35.

[10] OECD. OECD E-Government Flagship Report "The E-Government Imperative," Public Management Committee, Paris: OECD, 2003.

[11] U. Sivarajah, \& Z. Irani, "Exploring The Application Of Web 2.0 In EGovernment: A United Kingdom Context", tGov2012: Brunel University, University Kingdom, 2012.

[12] S. Krishnan, \& T.S. "Moderating effects of governance on information infrastructure and e-government development", Journal of the American Society for Information Science and Technology, 63(10), 2012.

[13] A.M. Al-Khouri, "E-government in Arab countries: A 6-staged roadmap to develop the public sector", Journal of management and Strategy, 4(1), $80,2013$.

[14] N. Nkwe, "E-government: challenges and opportunities in Botswana", International journal of humanities and social science, 2(17), 2012, 3948.

[15] B.C. Smith, "Good Governance and Development", New York: Palgrave Macmillan, 2007.

[16] P. Directorate, T. D. Committee, P. G. In, I., \& P. Service, “OCDE. Governance, Innovation in public service delivery”, OCDE, For Official Use, 2011.

[17] E. Lau, "E-government and the drive for growth and equity", Proceedings Conference From E-Gov to I-Gov, organization for economic cooperation and development e-government project, 2015.

[18] J. Lee, "10 year retrospect on stage models of e-Government: A qualitative meta-synthesis", Government Information Quarterly, 27(3), 2010, 220-230.

[19] M. Alshehri, \& S. Drew, "E-Government fundamentals". Paper presented at the IADIS International Conference ICT, Society and Human Beings, 2010.

[20] T.M. Waema, \& E.O. Adera, " Local governance and ICTs in Africa: case studies and guidelines for implementation and evaluation: IDRC", 2011.

[21] H. Alsaghier, M. Ford, A. Nguyen, \& R. Hexel, " Conceptualising citizen's trust in e-government: Application of Q methodology", Leading Issues in E-Government, 2011.

[22] Y.K. Dwivedi, V. Weerakkody, \& M. Janssen, " Moving towards maturity: challenges to successful e-government implementation and diffusion" ACM Sigmis Database, 42(4), 2012.

[23] M.W. Donker-Kuijer, M. de Jong, \& L. Lentz, " Usable guidelines for usable websites. An analysis of five e-government heuristics". Government Information Quarterly, 27(3), 2010, 254-263. 
[24] G. Udo, "Privacy Security Concerns as Major barriers for e-commerce: A survey study" in Information Management \& Computer Security, vol.9, no.4, 2001.

[25] U. Lofstedt, "E-government-assessment of current research and some proposals for future directions", International journal of public information systems, 1(1), 2012.

[26] M. Mustafa Kamal, \& M. Alsudairi, ” Investigating the importance of factors influencing integration technologies adoption in local government authorities". Transforming Government: People, Process and Policy, 3(3), 2009, 302-331

[27] R. Heeks, "Understanding and measuring e-government. International Benchmarking Studies, UNDESA workshop, E-Participation and EGovernment: Understanding the Present and Creating the Future", Budapest, Hungary, 27-28 July 2006.

[28] V. Ndou, "E-government for developing countries: opportunities and challenges", The Electronic Journal on Information Systems in Developing Countries; Volume 18, No.1, 2004.

[29] A. Meijer, et al, " Government 2.0: Key Challenges to Its Realization. Electronic Journal of e-Government", 10(1), 2012, 59 - 69

[30] S. Sharma, and J. Gupta, "Building Blocks of an E-government- A Framework", Journal of Electronic Commerce in Organizations, vol.1, no. 4, 2003.

[31] S. Dorji, " E-government initiatives in Bhutan: Government to Citizen (G2C) service delivery initiative-A case study", Murdoch University, 2012.

[32] A.N.H. Zaied, "Barriers to e-commerce adoption in Egyptian SMEs", International Journal of Information Engineering and Electronic Business, 4(3), 9, 2012.

[33] F. Bélanger, \& R.E. Crossler, " Privacy in the digital age: a review of information privacy research in information systems", MIS quarterly, 35(4), 2011, 1017-1042.

[34] S. Jackson, " Organizational culture and information systems adoption: A three-perspective approach"m Information and Organization, 21(2), 57-83, 2011.

[35] D.M. West, " State and Federal E-government in United States",2001.

[36] A. Carvin, J. Hill, and S.S. Smothers, "E-government for all: Ensuring equitable access to online government services", The EDC center for media \& community and the NYS forum, 2004.

[37] I.A. Alghamdi, , R. Goodwin, \& G. Rampersad, "E-government readiness assessment for government organizations in developing countries", Computer and Information Science, 4(3), 3, 2011.

[38] P.Mell, \& T. Grance, "The NIST definition of cloud computing", 2011.

[39] KPMG,"The Cloud: Changing the Business Ecosystem", Kpmg, 1-102, 2011.

[40] A. Abdulaziz," Cloud computing for increased business value", International Journal of Business and Social Science, 3(1), 2012.

[41] K. Vats, S. Sharma, \& A. Rathee,"A Review of Cloud Computing and eGovernance", International Journal of Advanced Research in Computer Science and Software Engineering, 2(2), 5, 2012.

[42] J. Liang," Government cloud: enhancing efficiency of e-government and providing better public services. Paper presented at the Service sciences (IJCSS)", international joint conference on Service Sciences, Service Innovation in Emerging Economy: Cross-Disciplinary and CrossCultural Perspective, 2012.

[43] A. E. Youssef," Exploring Cloud Computing Services and Applications", Journal of Emerging Trends in Computing and Information Sciences, 3, 2012.

[44] R. Kurdi, A. Taleb-Bendiab, M. Randles \& M. Taylor, "E-Government Information Systems and Cloud Computing (Readiness and Analysis)", In Developments in E-Systems Engineering (DeSE), IEEE, 404-409, 2011.

[45] T. Almarabeh, Y.K. Majdalawi, \& H. Mohammad, "Cloud Computing of E- Government. Communications and Network", 8(8), 2016, pp1-8.

[46] R.K. Das, S. Patnaik, \& A.K. Misro, " Adoption of cloud computing in e-governance Advanced Computing (pp. 161-172): Springer, 2011.
[47] R. Sharma, A. Sharma, \& R.R. Singh, "E-Governance \& Cloud Computing: Technology Oriented Government Policies", IJRIM 2(2), 2012.

[48] S. Alshomrani, and S. Qamar, "Cloud Based E-Government: Benefits and Challenges", International Journal of Multidisciplinary Sciences and Engineering, 4(6): 2013, pp. 1-7.

[49] V. Kundra,"State of Public Sector Cloud Computing", Federal Chief Information Officers Council, 2010.

[50] A. Rastogi," A model based approach to implement cloud computing in e-Governance", International Journal of Computer Applications, 9(7), 2010, pp15-18

[51] K.L. Bansal, S.K. Sharma, and S. Sood,'Impact of Cloud Computing in Implementing Cost Effective E-governance Operations", GIAN JYOTI E-JOURNAL, 1(2),2012.

[52] M. Bellamy, "Adoption of Cloud Computing Services by Public Sector Organisations", Paper presented at the Services (SERVICES), 203 IEEE Ninth World Congress, 2013.

[53] B. Zwattendorfer, \& A. Tauber, "The public cloud for e-government", International Journal of Distributed Systems and Technologies (IJDST), 4(4),2013, pp1-14.

[54] Al-ghanim, "Relationship and Cloud Factors Affecting Government Confidence in the Public Cloud", PhD Thesis, De Montfort University. United Kingdom, 2017.

[55] N. ALMutairi, \& S. Fahad Thuwaini, "Cloud Computing Uses for EGovernment in the Middle East Region Opportunities and Challenges", International Journal of Business and Management, 10(4), 2015.

[56] D. Woods, \& P. Hofmann, "Cloud computing: the limits of public clouds for business applications", Internet Computing, IEEE, 14(6), 90 93,2010.

[57] S. Subashini, \& V. Kavitha, "A survey on security issues in service delivery models of cloud computing", Journal of Network and Computer Applications, 2011.

[58] L. G. Tornatzky, M. Fleischer, \& A. K. Chakrabarti, “ Processes of technological innovation: Lexington Books”, 1990.

[59] F.D. Davis, "Perceived Usefulness, Perceived Ease of Use, and User Acceptance of Information Technology," MIS Quarterly (13:3), 1989, pp. 319-339.

[60] D.H. Shin, "User centric cloud service model in public sectors: policy implications of cloud services", Government Information Quarterly, 30(2), 2013,194-203.

[61] H. P. Borgman, B. Bahli, H. Heier, \& F. Schewski, "Cloud rise: Exploring cloud computing adoption and governance with the TOE framework". In Proceedings of the Annual Hawaii International Conference on System Sciences, 2013, pp. 4425-4435.

[62] M. Alsanea, "Factors Affecting the Adoption of Cloud Computing in Saudi Arabia's Government Sector", 2015.

[63] H. Trivedi, "Cloud computing adoption model for governments and large enterprises. Massachusetts Institute of Technology", 2013.

[64] M. A. Wahsh, \& J. S. Dhillon, "A systematic review of factors affecting the adoption of cloud computing for e-Government implementation", ARPN Journal of Engineering and Applied Sciences, 10(23), 2015a, 17824-17832

[65] R. Alotaibi, L. Houghton, K. Sandhu, "Factors Influencing Users' Intentions to Use Mobile Government Applications in Saudi Arabia: TAM Applicability", International Journal of Advanced Computer Science and Applications. 8, 200-211, 2017.

[66] K. Kavitha, "Study on Cloud Computing Model and its Benefits, Challenges", International Journal of Innovative Research in Computer and Communication Engineering, 2(1), 2423-2431, 2014.

[67] M. Oqail Ahmad, \& R. Zaman Khan," The Cloud Computing: A Systematic Review", International Journal of Innovative Research in Computer and Communication Engineering (An ISO Certified Organization), 2015.

[68] B. L. Sahu, \& R. Tiwari, "A comprehensive study on Cloud computing", International journal of Advanced Research in Computer science and Software engineering, 2(9), 2012.

[69] H.M. El-Bakri, “Cloud Computing in E-Government: A Survey”, 2015 
[70] Shiny ,"Load Balancing In Cloud Computing:A Review , Journal of Computer Engineering (IOSR-JCE) e-ISSN: 2278-0661,2013

[71] C. Ting, S. Xue, F. Tiong, \& W. Xin, " BENEFITS AND CHALLENGES OF THE ADOPTION OF CLOUD COMPUTING IN BUSINESS", International Journal on Cloud Computing: Services and Architecture (IJCCSA), 6(6), 1-15, 2016.

[72] M. Carroll, A. Van Der Merwe, \&P. Kotzé, "Secure Cloud Computing: Benefits, Risks and Controls", Information Security for South Africa, 1-9, 2011

[73] IDC, " Cloud Computing 2010 an IDC Update.", from IDC (International Data Corporation) Report. Update. IDC, 2009.

[74] H. Gangwar, H. Date, and R. Ramaswamy,“ Understanding determinants of cloud computing adoption using an integrated TAMTOE model", Journal of Enterprise Information Management. Vol. 28, 2015, pp. 107-130

[75] Y. Alshamaila, S. Papagiannidis, and F. Li, " Cloud computing adoption by SMEs in the north east of England", Journal of Enterprise Information Management [Online], 26(3), 2013, pp.250-275.

[76] T. Almarabeh, Y.K. Majdalawi, \& H. Mohammad, "Cloud Computing of E- Government. Communications and Network", 8(8), 1-8, 2016.

[77] M. Alsanea, \& D. Wainwright, "Identifying the Determinations of Cloud Computing Adoption in a Governement Sector- a Case Study of Saudi Organization", International Journal of Business and Management Studies, Vol 6, No 2, 2014.

[78] S.R. Tehrani, " Factors Influencing the Adoption of Cloud Computing by Small and Medium-Sized Enterprises (SMEs)", Ryerson University, 2013.

[79] C. Low, Y. Chen, and M. Wu, "Understanding the determinants of cloud computing adoption", Industrial management \& data systems. Vol. 111, 2011, pp. 1006-1023.

[80] O. Harfoushi, A.H. Akhorshaideh, N. Aqqad, M.A. Janini, \& R. Obiedat, "Factors Affecting the Intention of Adopting Cloud Computing in Jordanian Hospitals", Communications and Network, 08(02), 88-101, 2016.

[81] F. Mohammed, and O. Ibrahim, "Models of adopting cloud computing in the e-government context: a review", Jurnal Teknologi, 73 (2), 2015, pp. $51-59$

[82] H.M. El-Bakry, "Cloud Computing in E-Government: A Survey”, 2015.

[83] Mustafa Musa Jaber, Mohd Khanapi Abd Ghani1, Nanna Suryana Herman, "A Review Of Adoption Of Telemedicine In Middle East Countries: Toward Building Iraqi Telemedicine Framework, International Symposium on Research in Innovation and Sustainability", (ISoRIS '14) 15-16 October 2014, Malacca, Malaysia, Sci.Int. (Lahore), 26(5), 2014, pp. 1795-1800

[84] R. Johns, "Likert Items and Scales. Survey Question Bank: Methods Fact Sheet 1", 1-11,2010.

[85] A. Joshi, S. Kale, S. Chandel, D. Pal, "Likert Scale Explored and Explained", British Journal of Applied Science \& Technology. 7, 396403, 2015.

[86] S. a. Alateyah, R. R. M. Crowder, G. B. G. Wills, “ An Exploratory study of proposed factors to Adopt e-government Services Saudi Arabia as a case study", (IJACSA) International Journal of Advanced Computer Science and Applications. 2013, p. pp 57-66.

[87] M. A. Alanezi, "Factors Influencing Cloud Computing Adoption in Saudi Arabia's Private and Public Organizations: A Qualitative Evaluation". (IJACSA) International Journal of Advanced Computer Science and Applications ,9, 121-129, 2018. 